\title{
Influences of chia flour and the concentration of total solids on the characteristics of 'dulce de leche' from goat milk
}

\author{
Marcia Alves $\mathrm{CHAVES}^{1 *}$, Aloísio Henrique Pereira de SOUZA², Eliane COLLA², \\ Paulo Rodrigo Stival BITTENCCOURT ${ }^{4}$, Makoto MATSUSHITA ${ }^{5}$
}

\begin{abstract}
A factorial categorical design totalling six treatments was applied to investigate the influence of the substitution of corn starch with whole and partially defatted chia flour under the technical characteristics (centesimal composition, instrumental analyses, and sensory evaluation) and nutritional disorders (composition of fatty acids and index of the nutritional quality of the lipid fraction) of 'dulce de leche' concentrated to 72 and $78^{\circ} \mathrm{B}$. The treatments with chia flour concentrated to $72^{\circ} \mathrm{B}$ showed higher moisture content and lower compression force, and when the concentration range increased to $78^{\circ} \mathrm{B}$, the levels of total lipids amounted up to 1.40 times when compared to treatment with corn starch. The polyunsaturated fatty acids, particularly omega-3 and omega-6 levels, were higher in treatments with chia flour on both tracks of concentration, allowing a reduction in the atherogenic index and thrombogenic index effects and the $n-6 / n-3$ ratio. The treatments of 'dulce de leche' with a lower concentration of soluble solids obtained greater acceptance and consumer purchase intention. The application of whole chia flour in small proportions and in the concentration of $72{ }^{\circ} \mathrm{B}$ was the most appropriate under the studied conditions, showing improvement in the nutritional quality and with good technical aspects of candy made with goat milk.
\end{abstract}

Keywords: Salvia hispanica L.; polyunsaturated fatty acids; alpha-linolenic acids; thickening agent.

Practical Application: Evaluation of characteristics of 'dulce de leche' from goat's milk with chia flour.

\section{Introduction}

According to Yangilar (2013), goat milk is an undeniable source of food, because it has beneficial effects for health maintenance, with physiological functions in the nutrition of children and the elderly. The nutritional properties of milk have motivated greater interest in its consumption as a functional food, making it a current trend of healthy food in developed countries (Bevilacqua et al., 2001; Olalla et al., 2009). It is considered a source of protein of excellent quality, resulting from the proportion of essential amino acids that compose the goat milk, in addition to being highly digestible due to the higher percentage of fat globules with a diameter of less than $1.5 \mu \mathrm{m}$ (Furtado, 1985; Olalla et al., 2009).

In recent years, the production and processing of goat milk into products of added value has been shown to provide an alternative food source for people with intolerance and allergies to cow milk, as demonstrated by Ribeiro \& Ribeiro (2010). Several studies have reported on the development of dairy products with goat milk, such as cheeses (Sant'ana et al., 2013), fermented milk (Hanum et al, 2015; Paz et al., 2014; Ranadheera et al., 2012), and butter (Idoui et al., 2013).

However, there are few information about 'dulce de leche' production waking up interest in its production using goat milk.
'Dulce de leche' is a popular product in Latin American countries resulting from cooking milk with sugar until the desired concentration, to which other ingredients may be added, such as starches, in a proportion not exceeding $5 \mathrm{~g} / \mathrm{L}$ of milk (Brasil, 1997; Ranalli et al., 2012). According to Silva et al. (2014), the use of starch in 'dulce de leche' may contribute to its consistency and efficiency by the retention of water, helping to control the crystallisation of lactose, which confers a sandy soil texture to the final product.

Due to the processing characteristics, there are many variations of the ingredients used in processing 'dulce de leche'. Thus, the application of other components, in addition to the technical properties of this product, can provide nutritionally balanced food. Studies conducted by Capitanni et al. (2013), Reyes-Caudillo et al. (2008) and Salgado-Cruz et al. (2013) have demonstrated that chia (Salvia hispanica L.) presents soluble fibres, with an analogue behaviour to multiple hydrocolloids, presenting gelling properties and a stabiliser, which is of great interest in the development of new formulations of products. Another factor of great prominence in this oleaginous seed is the high content of polyunsaturated fatty acids (PUFA), particularly the alpha-linolenic acid precursor of the omega-3series, in addition to the high amount of protein, minerals, and polyphenols (Capitanni et al., 2013; Reyes-Caudillo et al., 2008; Simopoulos, 2011).

${ }^{1}$ Programa de Pós-graduação em Ciência de Alimentos - PPC, Universidade Estadual de Maringá - UEM, Maringá, PR, Brazil

${ }^{2}$ Instituto Federal do Mato Grosso do Sul - IFMS, Coxim, MS, Brazil

${ }^{3}$ Programa de Pós-graduação em Tecnologia de Alimentos - PPGTA, Universidade Tecnológica Federal do Paraná - UTFPR, Medianeira, PR, Brazil

${ }^{4}$ Departamento Acadêmico de Química - DAQUI, Universidade Tecnológica Federal do Paraná - UTFPR, Medianeira, PR, Brazil

${ }^{5}$ Departamento de Química - DQI, Universidade Estadual de Maringá - UEM, Maringá, PR, Brazil

*Corresponding author: marcia_alves_chaves@hotmail.com 
Noting the strong tendency to consume foods with functional properties, the objective of this study was to develop formulations of 'dulce de leche' from goat milk using whole chia flour (FCI) and partially defatted chia flour (FCPD) in place of corn starch (AM) in order to analyse the best point of concentration of total solids $\left(72\right.$ and $\left.78^{\circ} \mathrm{B}\right)$ in the technical aspects (instrumental analyses, centesimal composition, and sensory analysis) and nutritional disorders (composition of fatty acids and index of the nutritional quality of the lipid fraction) of this product.

\section{Materials and methods}

In natura goat milk ( $3.87 \mathrm{~g} / 100 \mathrm{~g}$ of fat) from the Saanen breed was obtained from a rural producer (Itaipulandia, Parana State, Brazil) according to the norms of good farming practices. Subsequently, the milk was subjected to heat treatment in pasteurised plates $\left(72-75^{\circ} \mathrm{C} / 15-20 \mathrm{~s}\right)$ and stored on a camera at $5{ }^{\circ} \mathrm{C} \pm 1{ }^{\circ} \mathrm{C}$. The fully and partially defatted chia flour was acquired from Giroil Agro Ltd (Santo Angelo, Rio Grande do Sul State, Brazil). The other ingredients used in the preparation of the 'dulce de leche' (sucrose, glucose syrup, AM and sodium bicarbonate) were purchased at a local market (Medianeira, Paraná State, Brazil).

\subsection{Randomised factorial design}

A statistical design was used to investigate the influence of the thickener agents, FCI and FCPD in place of AM, commonly used in processing on the characteristics of the 'dulce de leche' from goat milk submitted to two tracks of concentration: 72 and $78^{\circ} \mathrm{B}$ (Table 1). The value of each thickener was fixed at $1 \mathrm{~g} / \mathrm{L}$ of milk.

\subsection{Product development}

For the preparation of the product, homogenized sucrose $(450 \mathrm{~g})$ and bicarbonate of soda $(4.2 \mathrm{~g})$ were added to the milk (3L) until reaching the concentration of $60^{\circ} \mathrm{B}$. Glucose syrup $(6 \mathrm{~g})$ and thickening agent (FCI, FCPD, or AM) were added at $68^{\circ} \mathrm{B}$. The concentration process continued until the conditions stipulated (Table 1) being the product packaged $\left(75^{\circ} \mathrm{C} \pm 1{ }^{\circ} \mathrm{C}\right.$ ) in polypropylene packaging. The 'dulce de leche' was kept at a temperature of $25^{\circ} \mathrm{C} \pm 2{ }^{\circ} \mathrm{C}$ for 7 days until analysis, simulating commercial storage.

Table 1. Randomized factorial design used for 'dulce de leche' from goat milk.

\begin{tabular}{ccccc}
\hline \multirow{2}{*}{ Thickening agent } & \multirow{2}{*}{ Simbol } & \multirow{2}{*}{ Unit } & \multicolumn{2}{c}{ Level } \\
\cline { 4 - 5 } & & & -1 & +1 \\
\hline Corn starch $(\mathrm{g} / \mathrm{L})$ & $\mathrm{AM}$ & ${ }^{\circ} \mathrm{B}$ & 72 & 78 \\
Chia whole flour $(\mathrm{g} / \mathrm{L})$ & FCI & ${ }^{\circ} \mathrm{B}$ & 72 & 78 \\
Chia flour partially defatted $(\mathrm{g} / \mathrm{L})$ & FCPD & ${ }^{\circ} \mathrm{B}$ & 72 & 78 \\
\hline
\end{tabular}

$\mathrm{T} 1=1 \mathrm{~g} / \mathrm{L} \mathrm{AM}$ and $72^{\circ} \mathrm{B} ; \mathrm{T} 2=1 \mathrm{~g} / \mathrm{L}$ AM and $78^{\circ} \mathrm{B} ; \mathrm{T} 3=1 \mathrm{~g} / \mathrm{L} \mathrm{FCI}$ and $72^{\circ} \mathrm{B} ; \mathrm{T} 4=1 \mathrm{~g} / \mathrm{L}$ FCI and $78^{\circ} \mathrm{B} ; \mathrm{T} 5=1 \mathrm{~g} / \mathrm{L} \mathrm{FCPD}$ and $72^{\circ} \mathrm{B} ; \mathrm{T} 6=1 \mathrm{~g} / \mathrm{L}$ FCPD and $78^{\circ} \mathrm{B}$

\subsection{Concentration of soluble solids content and centesimal composition}

The concentration of soluble solids was determined by a refractometer (model ITT-6313, mark Kiltler, São Paulo, Brazil). The levels of moisture, ash, and protein (conversion factor of total nitrogen 6.38) were determined in accordance with Cunniff (1998). The total lipids were extracted by the technique of Bligh \& Dyer (1959), and the total carbohydrates (CT) were calculated by Equation 1 .

$\mathrm{CT}=100-($ moisture + ash + protein + total lipids $)$

\subsection{Instrumental texture and energy value}

The analysis was performed with texturometer equipment (model Stable Micro Systems, mark TA.HD plus, Surrey, England). The 'dulce de leche' was evaluated in its own package (capacity of $200 \mathrm{~g}$ ), and the following parameters were adopted for the tests: pre-test speed: $2.0 \mathrm{~mm} / \mathrm{s}^{-1}$; test speed: $1.0 \mathrm{~mm} / \mathrm{s}^{-1} ;$ post-test speed: $2.0 \mathrm{~mm} / \mathrm{s}^{-1}$; distance: $10.0 \mathrm{~mm}$; time: $5.0 \mathrm{~s}$; strength of contact: 5.0 g; probe: acrylic cylinder of $20.0 \mathrm{~mm}$ (P20). The result of the parameter of compression force was expressed in grams (g). For calculation of the energy value, a 'dulce de leche' mass of approximately $0.5 \mathrm{~g}$ was conducted to the calorimetry bomb (model C-200, mark Ika Works, Staufen, Germany) and the found values were expressed in $\mathrm{Kcal} / 100 \mathrm{~g}$.

\subsection{Colour parameters}

The colour of the 'dulce de leche' was determined using colourimeter equipment (model Chroma Metter CR-400s, mark Konica Minolta, Osaka, Japan).The coordinates of the CIE/LAB were $L^{*}$ (brightness), $a^{*}$ [shades of red $(a+)$ to green $(a-)$ ], and $b^{*}$ [shade of yellow $(b+)$ the blue $(b-)$ ]. The numerical values of $a^{*}$ and $b^{*}$ were used to calculate the hue angle $\left(h u e^{\circ}\right)$, which indicates the colour tone and chroma $\left(C^{*}\right)$, which indicates the colour saturation of the sample, as shown in Equations 2 and 3, respectively.

$h^{\mathrm{o}}=\operatorname{tg}^{-1}\left(\mathrm{~b}^{*} / \mathrm{a}^{*}\right)$

$C=\sqrt{\left(\mathrm{a}^{*}\right)^{2}+\left(\mathrm{b}^{*}\right)^{2}}$

The coordinates of $L^{*}, a^{*}$, and $b^{*}$ can calculate the $\Delta \mathrm{E}^{*}$, which indicates the difference in the 'perception' of colour, including the brightness, tone, and saturation of the tests prepared with chia flour compared to AM in the respective concentration band. The value of $\Delta \mathrm{E}^{\star}$ was calculated by Equation 4 .

$$
\Delta E^{*}=\sqrt{\left(\Delta L^{*}\right)^{2}+\left(\Delta a^{*}\right)^{2}+\left(\Delta b^{*}\right)^{2}}
$$

Where $\Delta \mathrm{L}^{*}=L^{*}$ (standard test with AM) - $L$ (test with FCI and FCPD); $\Delta \mathrm{a}^{*}=a^{*}$ (standard test with AM) $-a^{*}$ (test with FCI and FCPD); $\Delta \mathrm{b}^{*}=b^{*}$ (standard test with AM) - $b$ (test with FCI and FCPD). According to Cecchini et al. (2011), the greatest value of $\Delta \mathrm{E}^{\star}$ is the biggest difference between two colours, according to the following description: unnoticeable $\left(\Delta \mathrm{E}^{*}<1\right)$, minimal $\left(1 \leq \Delta \mathrm{E}^{\star}<2\right)$, only noticeable $\left(2 \leq \Delta \mathrm{E}^{*}<3\right)$, noticeable $\left(3 \leq \Delta \mathrm{E}^{*}<5\right)$, strong difference $\left(5 \leq \Delta E^{\star}<12\right)$, different colour $\left(\Delta E^{\star} \geq 12\right)$. 


\subsection{Composition of fatty acids}

The treatments of 'dulce de leche' suffered derivatization, and the methyl esters of the fatty acids were separated in a gas chromatograph (model 3380, mark Varian, USA) equipped with a fused silica capillary column (FAME, CP 7420-Select). The flow of gases was $1.4 \mathrm{~mL} / \mathrm{min}^{-1}$ for the carrier gas $\left(\mathrm{H}_{2}\right), 30 \mathrm{~mL} / \mathrm{min}^{-1}$ for the auxiliary gas $\left(\mathrm{N}_{2}\right)$, and 30 and $300 \mathrm{~mL} / \mathrm{min}^{-1}$ for the gases of the flame, hydrogen and synthetic air, respectively. The temperature of the injector and detector was kept at $235^{\circ} \mathrm{C}$. The column temperature was maintained at $65^{\circ} \mathrm{C}$ for $4 \mathrm{~min}$, reaching $4{ }^{\circ} \mathrm{C}$ min up to $185^{\circ} \mathrm{C}$ and maintained for $5 \mathrm{~min}$, then elevated from $185{ }^{\circ} \mathrm{C}$ to $10{ }^{\circ} \mathrm{C}$ min up to $225^{\circ} \mathrm{C}$ and maintained for $10 \mathrm{~min}$. The fatty acids were identified through the use of a mixture of methyl esters, and the retention times were compared (Sigma, USA). The normalized peak areas were determined through the software Star 5.0 (Varian, USA), and the concentrations were expressed in $\mathrm{g}$ of fatty acid per $100 \mathrm{~g}$ of lipid (g/100 g).

\subsection{Index of nutritional quality of the lipid fraction}

The atherogenic index (IAT) and thrombogenic index (IT) effects were calculated according to Equations 5 and 6, proposed by Ulbricht \& Southgate (1991).

$\mathrm{IAT}=[(12: 0+(4 \times 14: 0)+16: 0)] /(\mathrm{AGMI}+n-6+n-3)$

$\mathrm{IT}=[(14: 0+16: 0+18: 0) /[(0.5 \mathrm{x}$ AGMI $)+(0.5 \mathrm{x} n-6)+(3 \mathrm{x} n-3)+(n-3 / n-6)](6)$

Where: AGMI = monounsaturated fatty acids; $n-3=$ Omega 3 and $n-6=$ Omega 6

The reason for hypocholesterolemic and cholesterolemic fatty acids was calculated according to Equation 7, proposed by Santos-Silva et al. (2002).

$\mathrm{HH}=[(18: 1 n-9+18: 2 n-6+18: 3 n-3) /(14: 0+16: 0)]$

\subsection{Sensory analysis}

The sensory evaluation was performed after ethical approval (CAAE $\mathrm{n}^{\circ}$. 02186412.2.0000.0104) from the State University of Maringa (Maringá, Paraná State, Brazil). The treatments of 'dulce de leche' were coded with a three-digit random number and served monadically in an approximate amount of $25 \mathrm{~g}$, accompanied with salty crackers, a glass of water, and an evaluation sheet. A total of
80 non-trained judges were recruited to perform the acceptance test, in which the attributes of flavour, odour, colour, texture, appearance, and overall impression were evaluated through a nine-point hedonic scale, where ' 9 ' corresponds to the option 'I liked a lot' and ' 1 to the option 'I really disliked', according to Faria \& Yotsuyanagi (2008). The intention to purchase was determined using a five-point scale, where ' 1 ' was 'certainly not buying' and ' 5 ' was 'certainly buying. The acceptability index (IA) was calculated according to Equation 8.

$\mathrm{IA}(\%)=\mathrm{A} \times 100 / \mathrm{B}$

Where: $\mathrm{A}=$ average score obtained for the product and $\mathrm{B}=$ maximum score given to the product. The IA with a good effect is considered $\geq 70 \%$ (Lawless \& Heymann, 1999).

\subsection{Statistical analysis}

The averages of the triplicate samples were subjected to analysis of variance and when a significant difference at the $5 \%$ level of probability was detected, the Tukey test was applied through the Statistic program, version 7.0 (Statsoft, 2007).

\section{Results and Discussion}

The analysis of variance showed a significant difference in moisture content $(\mathrm{p}<0.05)$, as shown in Table 2 . The highest averages occurred in treatments with added FCI with lower concentrations of soluble solids (T3 and T5). Due to the increase in the evaporation process $\left(78^{\circ} \mathrm{B}\right)$, the treatments with FCI and FCPD differed from those submitted to $72{ }^{\circ} \mathrm{B}$, with slightly lower moisture content. However, these values in T4 and T6 still remained higher than those treatments with AM in both concentrations. According to Muñoz et al. (2012), the fibres present in chia seeds are able to retain 27 times more water than their own weight, which explains the higher moisture content in 'dulce de leche' with fully and partially defatted chia flour. The results of moisture content also influenced the instrumental texture, reducing the firmness in the treatments with chia flour.

The treatments of 'dulce de leche' with AM (T1 and T2) differed among themselves and from the others $(\mathrm{p}<0.05)$ in the parameter of compression force (Table 2). The lowest values found in treatments T3, T4, T5, and T6 may be related to the intrinsic composition of chia flour, which probably absorbed a greater quantity of water due to the presence of fibres, leading to a less consistent look in the 'dulce de leche'. The range of concentration

Table 2. Centesimal composition, compression force and energy value of treatments of 'dulce de leche' from goat milk.

\begin{tabular}{|c|c|c|c|c|c|c|}
\hline Treatments & $\begin{array}{l}\text { Moisture } \\
(\mathrm{g} / 100 \mathrm{~g})\end{array}$ & $\begin{array}{c}\text { Ash } \\
(\mathrm{g} / 100 \mathrm{~g})\end{array}$ & $\begin{array}{l}\text { Protein } \\
(\mathrm{g} / 100 \mathrm{~g})\end{array}$ & Sugar total (g/100 g) & Compression force (g) & $\begin{array}{l}\text { Energy value } \\
\text { (Kcal/100 g) }\end{array}$ \\
\hline $\mathrm{T} 1$ & $19.51 \pm 0.22^{c}$ & $2.19 \pm 0.17^{b}$ & $9.88 \pm 0.34^{b}$ & $68.63 \pm 0.67^{a}$ & $374.22 \pm 24.92^{c}$ & $364.00 \pm 2.05^{\mathrm{a}}$ \\
\hline $\mathrm{T} 2$ & $19.15 \pm 0.13^{\mathrm{d}}$ & $2.27 \pm 0.14^{\mathrm{ab}}$ & $10.10 \pm 0.02^{\mathrm{b}}$ & $68.71 \pm 0.19^{\mathrm{a}}$ & $742.41 \pm 27.47^{\mathrm{a}}$ & $368.02 \pm 1.25^{\mathrm{a}}$ \\
\hline $\mathrm{T} 3$ & $20.61 \pm 0.13^{\mathrm{a}}$ & $2.48 \pm 0.36^{\mathrm{ab}}$ & $10.66 \pm 0.34^{\mathrm{ab}}$ & $63.78 \pm 0.79^{b}$ & $178.73 \pm 14.24^{\mathrm{d}}$ & $353.00 \pm 1.70^{b c}$ \\
\hline $\mathrm{T} 4$ & $19.92 \pm 0.03^{\mathrm{b}}$ & $2.69 \pm 0.32^{\mathrm{ab}}$ & $10.77 \pm 0.32^{\mathrm{ab}}$ & $63.60 \pm 1.78^{b}$ & $665.17 \pm 12.88^{b}$ & $357.00 \pm 1.60^{\mathrm{b}}$ \\
\hline T5 & $20.68 \pm 0.08^{\mathrm{a}}$ & $2.62 \pm 0.02^{\mathrm{ab}}$ & $10.64 \pm 0.46^{\mathrm{ab}}$ & $64.65 \pm 0.27^{b}$ & $191.53 \pm 19.35^{\mathrm{d}}$ & $350.01 \pm 2.16^{c}$ \\
\hline T6 & $20.17 \pm 0.05^{\mathrm{b}}$ & $2.91 \pm 0.24^{\mathrm{a}}$ & $11.09 \pm 0.43^{\mathrm{a}}$ & $64.48 \pm 0.88^{\mathrm{b}}$ & $684.24 \pm 14.08^{\mathrm{b}}$ & $357.00 \pm 1.63^{\mathrm{b}}$ \\
\hline
\end{tabular}

Means followed by the same letter in the column do not differ by Tukey's test $(\mathrm{p}<0.05)$. 
also influenced the instrumental texture of 'dulce de leche', with greater compression forces in the treatments concentrated to $78^{\circ} \mathrm{B}$. This factor recurred in the sensory analysis, in which the largest concentration of 'dulce de leche' had the lowest averages for the attribute of texture.

Regarding the ash content, only the treatments $\mathrm{T} 1$ and T6 were statistically different $(\mathrm{p}<0.05)$, being observed the highest average for the 'dulce de leche' added of FCPD, concentrated at $78^{\circ} \mathrm{B}$. Although not significant, with the reduction in moisture content and increase of soluble solids, there was an increase in ash content when compared with the same thickening agent.

The protein levels remained higher in T6, differing from the treatments with the addition of AM ( $p<0.05)$. The results of the present study were higher than those found in the literature (Gaze et al., 2015; Madrona et al., 2009; Silva et al., 2014). Because of the lower proportion of moisture and total lipids in treatments with corn starch, it was observed increase in total carbohydrates in $\mathrm{T} 1$ and $\mathrm{T} 2$, with the highest results and differing statistically from the others $(\mathrm{p}<0.05)$. However, when comparing the same type of thickening, increase in the concentration of soluble solids content from 72 to $78^{\circ} \mathrm{B}$ did not influence the carbohydrate content in the treatments with FCI and FCPD.
Regarding the content of total lipids (Table 3 ), the treatments T3 and T6 showed no statistical differences between them $(\mathrm{p}<0.05)$ and remained higher in the two tracks of concentration studied.

The amount of lipids in 'dulce de leche' at $78^{\circ} \mathrm{B}$ increased by 1.40 and 1.26 times in $\mathrm{T} 4$ and $\mathrm{T} 6$, respectively, when compared to treatment with AM (T2). The increase in the lipid content can be observed when analysing the concentrations of PUFA, which were higher in treatments containing FCI, especially by increasing fatty alpha-linolenic acids in the treatment with FCI when compared to the others (FCPD and AM). This simultaneous increase of 5.75 and 4.70 times the value of omega- 3 in relation to the 'dulce de leche' with AM provided reduction in the ratio $n-6 / n-3$ by almost six times in treatment $\mathrm{T} 3$.

According to Simopoulos (2011), the reason $n-6 / n-3$ in western feeding is around $15-20 / 1$ and the addition of small doses of FCI and FCPD could contribute to the reduction of this index to values close to the recommended 1-2/1. Ratnayake \& Galli (2009) also reported that an imbalance in the intake of $n-6 / n-3$ is associated with conditions of myocardial infarction, hypercholesterolaemia, increased LDL cholesterol and blood pressure, formation of atheromatous plaque, dyslipidemia among other diseases.

Table 3. Composition of fatty acids ( $\mathrm{g} / 100 \mathrm{~g}$ of fatty acids) and index of nutritional quality of the lipid fraction of treatments of 'dulce de leche' from goat.

\begin{tabular}{|c|c|c|c|c|c|c|}
\hline Fattyacid & $\mathrm{T} 1$ & $\mathrm{~T} 2$ & $\mathrm{~T} 3$ & $\mathrm{~T} 4$ & T5 & T6 \\
\hline 4:0 & $0.37 \pm 0.02$ & $0.35 \pm 0.01$ & $0.38 \pm 0.04$ & $0.41 \pm 0.03$ & $0.45 \pm 0.02$ & $0.43 \pm 0.03$ \\
\hline $6: 0$ & $1.02 \pm 0.06$ & $0.99 \pm 0.01$ & $1.06 \pm 0.06$ & $1.13 \pm 0.07$ & $1.22 \pm 0.02$ & $1.20 \pm 0.03$ \\
\hline $8: 0$ & $2.13 \pm 0.09$ & $2.06 \pm 0.01$ & $2.13 \pm 0.06$ & $2.22 \pm 0.08$ & $2.35 \pm 0.06$ & $2.32 \pm 0.00$ \\
\hline $10: 0$ & $10.40 \pm 0.34$ & $10.16 \pm 0.04$ & $10.31 \pm 0.31$ & $10.44 \pm 0.14$ & $10.84 \pm 0.28$ & $10.74 \pm 0.09$ \\
\hline 11:0 & $0.27 \pm 0.01$ & $0.29 \pm 0.02$ & $0.27 \pm 0.01$ & $0.29 \pm 0.01$ & $0.29 \pm 0.01$ & $0.28 \pm 0.00$ \\
\hline $12: 0$ & $5.84 \pm 0.10$ & $5.77 \pm 0.05$ & $5.06 \pm 0.84$ & $5.73 \pm 0.00$ & $5.79 \pm 0.04$ & $5.80 \pm 0.02$ \\
\hline $15: 1$ & $0.84 \pm 0.05$ & $0.81 \pm 0.02$ & $0.79 \pm 0.02$ & $0.79 \pm 0.01$ & $0.78 \pm 0.02$ & $0.79 \pm 0.01$ \\
\hline $16: 0$ & $28.69 \pm 0.25$ & $29.10 \pm 0.13$ & $28.73 \pm 0.21$ & $28.34 \pm 0.18$ & $27.93 \pm 0.20$ & $28.05 \pm 0.02$ \\
\hline $16: 1$ & $1.23 \pm 0.04$ & $1.16 \pm 0.02$ & $1.14 \pm 0.03$ & $1.14 \pm 0.01$ & $1.18 \pm 0.01$ & $1.15 \pm 0.01$ \\
\hline $17: 0$ & $0.75 \pm 0.01$ & $0.84 \pm 0.04$ & $0.78 \pm 0.02$ & $0.77 \pm 0.00$ & $0.77 \pm 0.01$ & $0.76 \pm 0.02$ \\
\hline 18:0 & $7.19 \pm 0.15$ & $7.20 \pm 0.09$ & $7.17 \pm 0.04$ & $7.22 \pm 0.02$ & $7.22 \pm 0.10$ & $7.27 \pm 0.05$ \\
\hline Total lipids & $4.84 \pm 0.28^{c}$ & $4.94 \pm 0.11^{\mathrm{bc}}$ & $6.57 \pm 0.37^{\mathrm{a}}$ & $6.89 \pm 0.87^{a}$ & $6.02 \pm 0.11^{\mathrm{ab}}$ & $6.22 \pm 0.30^{\mathrm{a}}$ \\
\hline SCFA & $13.94 \pm 0.52^{\mathrm{ab}}$ & $13.56 \pm 0.04^{\mathrm{b}}$ & $13.88 \pm 0.41^{\mathrm{ab}}$ & $14.19 \pm 0.32^{\mathrm{ab}}$ & $14.86 \pm 0.33^{\mathrm{a}}$ & $14.69 \pm 0.04^{\mathrm{a}}$ \\
\hline SFA & $69.69 \pm 0.34^{\mathrm{a}}$ & $69.56 \pm 0.19^{\mathrm{a}}$ & $68.79 \pm 0.16^{\mathrm{b}}$ & $69.31 \pm 0.09^{\mathrm{ab}}$ & $69.51 \pm 0.24^{\mathrm{a}}$ & $69.55 \pm 0.03^{\mathrm{a}}$ \\
\hline MUFA & $26.60 \pm 0.22^{\mathrm{a}}$ & $26.71 \pm 0.14^{\mathrm{a}}$ & $26.15 \pm 0.15^{\mathrm{b}}$ & $26.09 \pm 0.06^{\mathrm{b}}$ & $26.15 \pm 0.09^{\mathrm{b}}$ & $26.34 \pm 0.01^{\mathrm{ab}}$ \\
\hline PUFA & $3.01 \pm 0.03^{\mathrm{d}}$ & $2.98 \pm 0.07^{\mathrm{d}}$ & $4.20 \pm 0.03^{\mathrm{a}}$ & $3.91 \pm 0.04^{\mathrm{b}}$ & $3.33 \pm 0.07^{\mathrm{c}}$ & $3.28 \pm 0.02^{c}$ \\
\hline $18: 2 n-6(n-6)$ & $2.81 \pm 0.03^{\mathrm{b}}$ & $2.78 \pm 0.05^{\mathrm{b}}$ & $3.05 \pm 0.02^{\mathrm{a}}$ & $2.97 \pm 0.03^{\mathrm{a}}$ & $2.83 \pm 0.05^{\mathrm{b}}$ & $2.83 \pm 0.02^{\mathrm{b}}$ \\
\hline $18: 3 n-3(n-3)$ & $0.20 \pm 0.01^{\mathrm{d}}$ & $0.20 \pm 0.03^{\mathrm{d}}$ & $1.15 \pm 0.05^{\mathrm{a}}$ & $0.94 \pm 0.00^{\mathrm{b}}$ & $0.50 \pm 0.02^{c}$ & $0.45 \pm 0.00^{c}$ \\
\hline$n-6 / n-3$ & $14.02 \pm 0.97^{\mathrm{a}}$ & $14.36 \pm 2.00^{\mathrm{a}}$ & $2.65 \pm 0.12^{c}$ & $3.15 \pm 0.03^{c}$ & $5.64 \pm 0.21^{\mathrm{bc}}$ & $6.24 \pm 0.00^{\mathrm{b}}$ \\
\hline IAT & $2.72 \pm 0.03^{\mathrm{a}}$ & $2.72 \pm 0.02^{\mathrm{a}}$ & $2.62 \pm 0.01^{\mathrm{b}}$ & $2.64 \pm 0.01^{\mathrm{b}}$ & $2.66 \pm 0.01^{\mathrm{b}}$ & $2.66 \pm 0.01^{\mathrm{b}}$ \\
\hline IT & $3.08 \pm 0.01^{\mathrm{a}}$ & $3.09 \pm 0.03^{\mathrm{a}}$ & $2.57 \pm 0.03^{\mathrm{d}}$ & $2.65 \pm 0.01^{\mathrm{c}}$ & $2.86 \pm 0.02^{\mathrm{b}}$ & $2.89 \pm 0.01^{\mathrm{b}}$ \\
\hline $\mathrm{H} / \mathrm{H}$ & $0.64 \pm 0.00^{\mathrm{b}}$ & $0.64 \pm 0.00^{\mathrm{b}}$ & $0.66 \pm 0.00^{\mathrm{a}}$ & $0.66 \pm 0.00^{\mathrm{a}}$ & $0.66 \pm 0.00^{\mathrm{a}}$ & $0.66 \pm 0.01^{\mathrm{a}}$ \\
\hline
\end{tabular}

SCFA= Short-Chain Fatty Acids; SFA= Saturated Fatty Acids; MUFA= Monounsaturated Fatty Acids; PUFA= Polyunsaturated Fatty Acids; $18: 2 n-6$ ( $n 6$ ): Linoleic acid (omega-6); 18:3n-3 $(n-3)=$ Linolenic acid (omega-3); n-6/n-3: Ratio omega-6/omega-3; IAT= Atherogenic Index; IT = Thrombogenic Index; HH=Ratio Hypocholesterolaemic FattyAcids/Hypercholesterolemic Fatty Acids. Means followed by the same letter in the line do not differ by Tukey's test $(\mathrm{p}<0.05)$. 
Regarding the IAT and IT (Table 3), the treatments with FCI and FCPD presented lower values when compared to treatment with AM. For the IT, it was also noted that the treatments with FCI differed among themselves and the others $(\mathrm{p}<0.05)$, and the lowest average for this index occurred in T3. This result is associated with a greater concentration of fatty acid alpha-linolenic acid, which has an antithrombogenic effect superior to omega 6 fatty acids. According to Sousa Bentes et al. (2009), there are no recommended values for the IAT and IT in dairy products; therefore, it is considered that the lower the occurrence of these values, the more favourable the profile of fatty acids on human health.

The same is true for why hypocholesteromic and hypercholesterolemic fatty acids are not prescribed as a reference value for dairy products. The literature uses as a standard of comparison the value 2.0, assigned to meat products; however, in the present study the rates remained below 1.0 for all treatments, but were slightly higher in 'dulce de leche' with FCI and FCPD. This result with low $\mathrm{H} / \mathrm{H}$ is influenced by the high content of myristic (14:0) and palmitic acid (16:0), which represent more than $55 \%$ of the total fatty acids in the treatment of 'dulce de leche'. As for the other fatty acids, significant concentrations (13.56 to $14.86 \mathrm{~g} / 100 \mathrm{~g}$ lipids) of short-chain fatty acids (4:0 to 10:0) are noted that are characteristic of goat milk, as demonstrated by Molina et al. (2015).

In the same way, the treatments T3 to T6 showed the lowest values of total energy, differing from T1 and T2 (Table 2). As mentioned, chia flour has a high fibre content that is not digested and absorbed by the gastrointestinal system, thus not counting as an energy source for the body (Stauffer, 1997). The substitution of corn starch with Partially defatted chia flour reduced $14 \mathrm{kcal} / 100 \mathrm{~g}$ in $\mathrm{T} 5$, which represents a decrease of $84 \mathrm{Kcal} /$ month for an individual who consumes a daily portion of $20 \mathrm{~g}$ of 'dulce de leche'. It appears that the quantity of FCI and FCPD (1 g/L) applied to the 'dulce de leche' was enough to promote beneficial effects on the composition of the product, enabling improvement in the nutritional quality even in foods with high energy demand such as 'dulce de leche'. Regarding the colour parameters (Table 4$)$, the treatments did not differ $(\mathrm{p}<0.05)$ in $L^{*}, a^{*}$, and $b^{\star}$, featuring a tint in the region between red $\left(a^{*}+\right)$ and yellow $\left(b^{*}+\right)$ with values of the hue angle situated between 66.02 and 67.24 hue. Note that the 'dulce de leche' showed a dark colour $\left(L^{\star}<50\right)$ and values of $C^{\star}$ between 25.97 and 31.01, demonstrating a more intense colour. The treatments with chia flour did not differ significantly among themselves $(\mathrm{p}<0.05)$ for the parameter $\Delta \mathrm{E}^{\star}$, and when compared to treatments with $\mathrm{AM}$ the colour difference was noticeable; colour distinctions were also identified during the sensory analysis. Evaluating the low luminosity, the slope of the hue angle, and the chromaticity of $a^{*}$ and $b^{*}$ positive, it can be assumed that the combination of these parameters resulted in 'dulce de leche' with a brown colour, characteristic of this product, due to reactions during cooking, enhanced by the addition of sodium bicarbonate.

In the sensorial analysis (Table 5), the attributes of taste, odour, and overall evaluation showed no significant differences among treatments $(\mathrm{p}<0.05)$. In the colour and appearance attributes, the average achieved in treatments T3, T4, T5, and T6 may have been influenced by the presence of dark spots due to the low solubility of FCI during processing of 'dulce de leche', indicated by some judges as appearing burned. For the texture, the treatments with different types of thickener subjected to the same conditions of concentration showed no difference between them $(\mathrm{p}<0.05)$. The same effect was observed in the evaluation of instrumental texture, in which the compression force was smaller at $72^{\circ} \mathrm{B}$. This allows verification that the chia flour in the used proportions did not influence the texture assigned to the 'dulce de leche' by the judges.

Table 4. Color parameters of treatments of 'dulce de leche' from goat milk.

\begin{tabular}{|c|c|c|c|c|c|c|}
\hline \multirow{2}{*}{ Treatments } & \multicolumn{6}{|c|}{ Color parameters } \\
\hline & $L^{*}$ & $a^{*}$ & $b^{*}$ & $h u e^{\circ}$ & $C^{*}$ & $\Delta \mathrm{E}^{*}$ \\
\hline $\mathrm{T} 1$ & $43.18 \pm 1.04^{\mathrm{a}}$ & $12.78 \pm 0.57^{\mathrm{a}}$ & $25.91 \pm 0.19^{\mathrm{a}}$ & $66.08 \pm 1.28^{\mathrm{a}}$ & $25.97 \pm 1.05^{b}$ & - \\
\hline $\mathrm{T} 2$ & $41.80 \pm 0.95^{\mathrm{a}}$ & $12.91 \pm 0.91^{\mathrm{a}}$ & $24.70 \pm 0.81^{\mathrm{a}}$ & $66.02 \pm 0.63^{\mathrm{a}}$ & $31.01 \pm 0.74^{\mathrm{a}}$ & - \\
\hline $\mathrm{T} 3$ & $43.06 \pm 0.21^{\mathrm{a}}$ & $13.33 \pm 0.23^{\mathrm{a}}$ & $25.07 \pm 0.78^{\mathrm{a}}$ & $67.24 \pm 0.95^{\mathrm{a}}$ & $27.86 \pm 1.85^{\mathrm{ab}}$ & $3.97 \pm 1.18^{\mathrm{a}}$ \\
\hline $\mathrm{T} 4$ & $42.17 \pm 0.99^{\mathrm{a}}$ & $13.97 \pm 1.57^{\mathrm{a}}$ & $24.46 \pm 1.70^{\mathrm{a}}$ & $66.22 \pm 0.38^{\mathrm{a}}$ & $29.33 \pm 1.77^{\mathrm{ab}}$ & $2.42 \pm 2.03^{\mathrm{a}}$ \\
\hline $\mathrm{T} 5$ & $43.28 \pm 0.84^{\mathrm{a}}$ & $13.72 \pm 0.20^{\mathrm{a}}$ & $25.03 \pm 0.23^{\mathrm{a}}$ & $67.15 \pm 0.47^{\mathrm{a}}$ & $28.24 \pm 0.79^{\mathrm{ab}}$ & $3.27 \pm 0.68^{\mathrm{a}}$ \\
\hline T6 & $42.78 \pm 0.28^{\mathrm{a}}$ & $13.89 \pm 0.59^{\mathrm{a}}$ & $24.68 \pm 0.81^{\mathrm{a}}$ & $66.90 \pm 1.07^{\mathrm{a}}$ & $29.04 \pm 0.27^{\mathrm{ab}}$ & $2.48 \pm 0.90^{\mathrm{a}}$ \\
\hline
\end{tabular}

Means followed by the same letter in the column do not differ by Tukey's test $(\mathrm{p}<0.05)$.

Table 5. Sensory atributes of treatments of 'dulce de leche' from goat milk.

\begin{tabular}{|c|c|c|c|c|c|c|c|}
\hline Treatments & Color & Flavor & Odor & Texture & Appearance & Global evaluation & $\begin{array}{c}\text { IA (\%) } \\
\text { Global evaluation }\end{array}$ \\
\hline $\mathrm{T} 1$ & $7.81 \pm 0.87^{\mathrm{a}}$ & $7.60 \pm 1.25^{\mathrm{a}}$ & $7.40 \pm 1.12^{\mathrm{a}}$ & $7.33 \pm 0.98^{\mathrm{a}}$ & $7.78 \pm 0.87^{\mathrm{a}}$ & $7.61 \pm 0.94^{\mathrm{a}}$ & 84.58 \\
\hline $\mathrm{T} 2$ & $7.68 \pm 0.96^{\mathrm{ab}}$ & $7.70 \pm 1.33^{\mathrm{a}}$ & $7.20 \pm 1.22^{\mathrm{a}}$ & $6.46 \pm 1.52^{\mathrm{b}}$ & $7.45 \pm 1.16^{\mathrm{ab}}$ & $7.38 \pm 1.12^{\mathrm{a}}$ & 81.94 \\
\hline $\mathrm{T} 3$ & $7.34 \pm 0.88^{\mathrm{b}}$ & $7.63 \pm 1.12^{\mathrm{a}}$ & $6.88 \pm 1.23^{\mathrm{a}}$ & $7.38 \pm 1.10^{\mathrm{a}}$ & $7.00 \pm 1.13^{c}$ & $7.43 \pm 0.86^{a}$ & 82.50 \\
\hline $\mathrm{T} 4$ & $7.23 \pm 1.34^{\mathrm{b}}$ & $7.43 \pm 1.30^{\mathrm{a}}$ & $7.01 \pm 1.23^{\mathrm{a}}$ & $6.39 \pm 1.60^{\mathrm{b}}$ & $7.04 \pm 1.21^{\mathrm{c}}$ & $7.24 \pm 1.22^{\mathrm{a}}$ & 80.42 \\
\hline $\mathrm{T} 5$ & $7.31 \pm 0.90^{\mathrm{b}}$ & $7.44 \pm 1.46^{\mathrm{a}}$ & $6.94 \pm 1.25^{\mathrm{a}}$ & $7.51 \pm 0.95^{\mathrm{a}}$ & $7.10 \pm 1.06^{c}$ & $7.41 \pm 0.98^{\mathrm{a}}$ & 82.36 \\
\hline T6 & $7.31 \pm 1.06^{b}$ & $7.51 \pm 1.40^{\mathrm{a}}$ & $7.23 \pm 1.24^{\mathrm{a}}$ & $6.70 \pm 1.44^{\mathrm{b}}$ & $7.23 \pm 1.16^{c}$ & $7.33 \pm 1.15^{\mathrm{a}}$ & 81.39 \\
\hline
\end{tabular}

$\mathrm{IA}=$ Acceptability index. Means followed by the same letter in the column do not differ by Tukey's test $(\mathrm{p}<0.05)$ 
The IA remained above the recommended value for the six treatments in all attributes analyzed, with emphasis on the global assessment, exceeding $80 \%$ acceptance (Table 5).For the purchase intention, the judges also attributed higher notes to the treatments concentrated to $72{ }^{\circ} \mathrm{B}$. When comparing the different thickeners under the same conditions of concentration, the sum of notes 4 (possibly buy) and 5 (certainly would buy) remained higher in T1 (72.50\%), T3 (58.72\%), and T5 (61.25\%) when compared to $\mathrm{T} 2(62.50 \%), \mathrm{T} 4(51.25 \%)$, and T6 (53.75\%). These results demonstrate that the type of thickener used would not be a determining factor in the acquisition of 'dulce de leche', because, for the 6 treatments, only $1 \mathrm{~g} / \mathrm{L}$ of thickening agent was used. According to the judges, the most relevant aspect is the concentration range, which probably led to an increase in consistency by removal of water during the evaporation process to $78^{\circ} \mathrm{B}$, with a decrease in consumer acceptance. Konkel et al. (2004) indicated that high concentrations of starch in commercial milk jam showed lower average acceptance when compared to milk jams with quantities of starch within the legal limits (maximum of $5 \mathrm{~g} / \mathrm{L}$ ).

\section{Conclusion}

The addition of $1 \mathrm{~g} / \mathrm{L}$ of fully and partially defatted chia enabled the development of 'dulce de leche' with an increment of mono- and polyunsaturated fatty acids, with omega- 3 and omega- 6 , reducing the $n-6 / n-3$ ratio, the IAT and IT effects, and the energy value. The treatments with FCI and FCPD also showed higher moisture content, reflecting in lower compression force on instrumental analysis of texture. The treatments concentrated at $72{ }^{\circ} \mathrm{B}$ were also considered of better sensorial acceptance by consumers. The chia flour proved difficult to solubilise, which was noticeable in the colour parameters and sensory analysis when compared to treatment with AM. The IA was greater than $70 \%$ in six treatments in all evaluated attributes. Therefore, the use of chia is promising, mainly in the form of a thickening agent up to the concentration of $72^{\circ} \mathrm{B}$ in 'dulce de leche' from goat milk.

\section{Acknowledgements}

To the State University of Maringá and Federal Technological University of Paraná for making the resources and technology available to support the development of this research.

\section{References}

Bevilacqua, C., Martin, P., Candalh, C., Fauquant, J., Piot, M., Roucayrol, A. M., Pilla, F., \& Heyman, M. (2001). Goat's milk of defective as ${ }_{1}^{-}$ casein genotype decreases intestinal and systemic sensitisation to b-lactoglobulin in guinea pigs. The Journal of Dairy Research, 68(2), 217-227. PMid:11504386. http://dx.doi.org/10.1017/S0022029901004861.

Bligh, E. G., \& Dyer, W. J. (1959). A rapid method of total lipid extraction and purification. Canadian Journal of Biochemistry and Physiology, 37(8), 911-917. PMid:13671378. http://dx.doi.org/10.1139/o59-099.

Brasil, Ministério da Agricultura, Pecuária e Abastecimento. (1997, September 4). Dispõe sobre o Regulamento Técnico para Fixação de Identidade e Qualidade de Doce de Leite. (Portaria no 354 de 04 de setembro de 1997). Diário Oficial [da] República Federativa do Brasil.

Capitanni, M. I., Ixtaina, V. Y., Nolasco, S. M., \& Tomás, M. C. (2013). Microstructure, chemical composition and mucilage exudation of chia
(Salvia hispanica L.) nutlets from Argentina. Journal of Agricultural and Food Chemistry, 93(15), 3856-3862. PMid:23900918. http:// dx.doi.org/10.1002/jsfa.6327.

Cecchini, M., Contini, M., Massantini, R., Monarca, D., \& Moscetti, R. (2011). Effects of controlled atmospheres and low temperature on storability of chestnuts manually and mechanically harvested. Postharvest Biology and Technology, 61(2), 131-136. http://dx.doi. org/10.1016/j.postharvbio.2011.03.001.

Cunniff, P. A. (1998). Official Methods of Analysis of AOAC International (16. ed.). Arlington: AOAC.

Faria, E. V., \& Yotsuyanagi, K. (2008). Técnicas de análise sensorial (2. ed.). Campinas: ITAL.

Furtado, M. (1985). Fabricação de queijos de cabra (6. ed). São Paulo: Nobel S.A.

Gaze, L. V., Costa, M. P., Monteiro, M. L., Lavorato, J. A., Conte Júnior, C. A., Raices, R. S., Cruz, A. G., \& Freitas, M. Q. (2015). Dulce de Leche, a typical product of Latin America: Characterisation by physicochemical, optical and instrumental methods. Food Chemistry, 169, 471-477. PMid:25236253. http://dx.doi.org/10.1016/j. foodchem.2014.08.017.

Hanum, Z., Sumantri, C., Purwantiningsih, Batubra, I., Taufik, E., Mitsunaga, T., Yamauachi, K., \& Ogata, Y. (2015). Effectivity of fermented goat milk added Lactobacillus plantarum asmelanin inhibitor. Applied Research Journal, 1(5), 338-342.

Idoui, T., Rechak, H., \& Zabayou, N. (2013). Microbial quality, physicochemical characteristics and fatty acid composition of a traditional butter made from goat milk. Annals Food Science and Technology, 14(1), 108-114. http://dx.doi.org/10.3989/gya.110209.

Konkel, F. E., Oliveira, S. M. R., Simões, D. R. S., \& Demiate, I. M. (2004). Avaliação sensorial de doce de leite pastoso com diferentes concentrações de amido. Food Science and Technology (Campinas), 24(2), 249-254. http://dx.doi.org/10.1590/S0101-20612004000200015.

Lawless, H. T., \& Heymann, H. (1999). Sensory evaluation of food: principles and practices. Gaithersburg: Aspen Publishers.

Madrona, G. S., Zotarelli, M. F., Bergamasco, R., \& Branco, I. G. (2009). Study on the effect of the addition of whey in the sensorial quality of creamy dulce de leche. Food Science and Technology (Campinas), 29(4), 826-833. http://dx.doi.org/10.1590/S0101-20612009000400020.

Molina, B., Alcalde, C. R., Hygino, B., Santos, S. M. A., Gomes, L. C., \& Santos, G. T. (2015). Inclusion of protected fat in diets on the milk production and composition of saanen goats. Ciência e Agrotecnologia, 39(2), 164-172. http://dx.doi.org/10.1590/S141370542015000200008.

Muñoz, L. A., Aguilera, J. M., Rodriguez-Turienzo, B. L., Cobos, A. A., \& Diaz, A. (2012). Characterization and microstructure of films made from mucilage of Salvia hispanica and whey protein concentrate. Journal of Food Engineering, 111(3), 511-518. http:// dx.doi.org/10.1016/j.jfoodeng.2012.02.031.

Olalla, M., Ruiz-Lópoz, M. D., Navarro, M., Artacho, R., Cabrera, C., Giménez, R., Rodriguez, C., \& Mingorance, R. (2009). Nitrogen fractions of Andalusian goat milk compared to similar types of commercial milk. Food Chemistry, 113(3), 835-838. http://dx.doi. org/10.1016/j.foodchem.2008.10.022.

Paz, N. F., Oliveira, E. G., Kairuz, M. S. N., \& Ramón, A. N. (2014). Characterization of goat milk and potentially symbiotic non-fat yogurt. Food Science and Technology (Campinas), 34(3), 629-635. http://dx.doi.org/10.1590/1678-457x.6409.

Ranadheera, C. S., Evans, C. A., Adams, M. C., \& Baines, S. K. (2012). Probiotic viability and physico-chemical and sensory properties of plain and stirred fruit yogurts made from goat's milk. Food Chemistry, 
135(3), 1411-1418. PMid:22953874. http://dx.doi.org/10.1016/j. foodchem.2012.06.025.

Ranalli, N., Andrés, S. C., \& Califano, A. N. (2012). Physicochemical and rheological characterization of "Dulce de Leche". Journal of Texture Studies, 43(2), 115-123. http://dx.doi.org/10.1111/j.17454603.2011.00321.x.

Ratnayake, W. M., \& Galli, C. (2009). Fat and fatty acid terminology, methods of analysis and fat digestion and metabolism: a background review paper. Annals of Nutrition \& Metabolism, 55(1-3), 8-43. PMid:19752534. http://dx.doi.org/10.1159/000228994.

Reyes-Caudillo, E., Tecante, A., \& Valdivia-López, M. A. (2008). Dietary fibre content and antioxidant activity of phenolic compounds present in Mexican chia (Salvia hispanica L.) seeds. Food Chemistry, 107(2), 656-673. http://dx.doi.org/10.1016/j.foodchem.2007.08.062.

Ribeiro, A. C., \& Ribeiro, S. D. A. (2010). Specialty products made from goat milk. Small Ruminant Research, 89(2-3), 225-233. http:// dx.doi.org/10.1016/j.smallrumres.2009.12.048.

Salgado-Cruz, M. P., Calderón-Domíngueza, G., Chanona-Péreza, J., Farrera-Rebolloa, R. R., Méndez-Méndezb, J. V., \& Díaz-Ramíreza, M. (2013). Chia (Salvia hispanica L.) seed mucilage release characterisation. A microstructural and image analysis study. Industrial Crops and Products, 51, 453-462. http://dx.doi.org/10.1016/j.indcrop.2013.09.036.

Sant'ana, A. M., Bezerril, F. F., Madruga, M. S., Batista, A. S., Magnani, M., Souza, E. L., \& Queiroga, R. C. (2013). Nutritional and sensory characteristics of Minas fresh cheese made with goat milk, cow milk, or a mixture of both. Journal of Dairy Science, 96(12), 7442-7453. PMid:24140324. http://dx.doi.org/10.3168/jds.2013-6915.
Santos-Silva, J., Bessa, R. J. B., \& Santos-Silva, F. (2002). Effect of genotype, feeding system and slaughter weight on the quality of light lambs: II. Fatty acid composition of meat. Livestock Production Science, 77(2-3), 187-194. http://dx.doi.org/10.1016/S0301-6226(02)00059-3.

Silva, F. L., Ferreira, H. A. L., Souza, A. B., Almeida, D. F., Stephani, R., Pirozi, M. R., Carvalho, A. F., \& Perrone, I. T. (2014). Production of dulce de leche: the effect of starch addition. LWT - Food Science and Technology, 62(1), 1-7. http://dx.doi.org/10.1016/j.lwt.2014.10.062.

Simopoulos, A. P. (2011). Evolutionary aspects of diet: the omega-6/ omega-3 ratio and the brain. Molecular Neurobiology, 44(2), 203215. PMid:21279554. http://dx.doi.org/10.1007/s12035-010-8162-0.

Sousa-Bentes, A., Souza, H.L., Simões, M. G., \& Mendonça, X. M. F. D. (2009). Caracterização física e química e perfil lipídico de três espécies de peixes amazônicos. Revista Brasileira de Tecnologia Agroindustrial, 3(2), 97-108. http://dx.doi.org/10.3895/S198136862009000200011 .

Statsoft. (2007). Statistica: data analysis software system, version 7.0. Tulsa: Statsoft Inc.

Stauffer, C. E. (1997). Principles of dough formation. In S. P. Cauvan \& L. S. Young (Eds.), Technology of bread making (pp. 262-295). London: Blackie Academicand Professional.

Ulbricht, T. L. V. \& Southgate, D.A.T. (1991). Coronary heart disease: seven dietary factors. Lancet, 338(8773), 985-992.

Yangilar, F. (2013). As potentially functional food: goats' milk and products. Journal of Food and Nutrition Research, 1(4), 68-81. http:// dx.doi.org/0.12691/jfnr-1-4-6. 